\title{
Baca Tulis Al Qur'an dengan Metode Jet Tempur di Madrasah Ibtidaiyah Matholiul Falah Payaman Ngraho Bojonegoro
}

\author{
${ }^{1}$ M. Romadlon Habibullah, ${ }^{2}$ Mukholidatul Musthofiah, ${ }^{3}$ Hamidatun Nihayah. \\ Prodi PGMI Fakultas Tarbiyah Unu sunan Giri Bojonegoro \\ E-mail: romadlon@sunan-giri.ac.id
}

\begin{abstract}
Abstrak
Penelitian ini dilatarbelakagi banyaknya anak yang belum mampu membaca al Qur'an dengan benar. Hal ini disebabkan karena anak zaman sekarang terbiasa menggunakan gadget daripada membaca al Qur'an. MI Matholiul Falah Payaman Ngraho Bojonegoro merupakan Madrasah yang memiliki program pembiasaan baca tulis al Qur'an hampir setiap hari dan Madrasah ini menggunakan metode yang berbeda daripada metode baca tulis al Qur'an yang diajarkan di berbagai instansi lainnya. fokus penelitian berkaitan tentang bagaimana proses pembelajaran baca tulis al Qur'an dengan metode jet tempur, faktor pendukung dan faktor penghambatnya. Jenis penelitian yang digunakan adalah Penelitian ini menggunakan pendekatan deskriptif kualitatif. analisis data menggunakan reduksi data, penyadian data, verifikasi dan kesimpulan. Hasil penelitiannya adalah (1) proses pembelajarannya dilaksanakan setiap hari selasa, kamis dan ahad. Di bagi menjadi 3 tingkatan pemula, lanjutan, dan tahfidz. Proses pembelajaran baca tulis al Qur'an dimulai dari membaca al Qur'an Membaca surat alfatihah dan surat-surat pendek sesuai dengan tingkatannya. Membaca materi yang ada di jet tempur sesuai tingkatannya, Menulis materi yang ada di jet tempur sesuai tingkatannya, (2) faktor pendukungnya adalah Kemampuan pendidik dalam menguasai materi, keaktifan peserta didik dalam pembelajaran, manajemen kelas. (3) faktor penghambatnya adalah kurangnya media pembelajaran, Monotonnya pendidik dalam menyampaikan materi, kedisiplinan siswa.
\end{abstract}

Kata Kunci : Baca, Tulis, al Qur'an dan Jet Tempur

\begin{abstract}
This research is motivated by children who have not been able to read the Qur'an properly. This is because today's children are accustomed to using gadgets instead of reading the Qur'an. MI Matholiul Falah Payaman Ngraho Bojonegoro is a Madrasah that has a program of reading and writing the Koran almost every day and this Madrasa uses a different method than the method of reading and writing the Koran taught in various other institutions. the focus of the research is on how the process of learning to read and write the Qur'an with the fighter jet method, the supporting factors and the inhibiting factors. The type of research used is this research using a qualitative descriptive approach. data analysis using data reduction, data encoding, verification and conclusion. The results of the research are (1) the learning process is carried out every Tuesday, Thursday and Sunday. Divided into 3 levels beginner, advanced, and tahfidz. The process of learning to read and write the Qur'an starts from reading the Qur'an Reading the letters alfatihah and short letters according to their level. Reading the material on the fighter jet according to its level, writing the material on the fighter jet according to the level, (2) the supporting factors are the ability of educators to master the material, the activeness of students in learning, class management. (3) the inhibiting factors are the lack of learning media, the monotony of educators in delivering the material, student discipline.
\end{abstract}

Keywords: Read, Write, Qur'an and Jet Fighter

https://doi.org/. 


\section{PENDAHULUAN}

Al Qur'an merupakan kalam Allah yang diwahyukan kepada Nabi Muhammad SAW melalui perantara malaikat Jibril selama kurang lebih dua puluh tiga tahun. Kandungan dalam al Qur'an merupakan pesan ilahi yang disampaikan oleh Nabi Muhammad SAW yang mana menjadi landasan kehidupan individual dan sosial bagi kaum muslimin dalam segala aspek, bahkan umat islam mengawali eksistensinnya dan telah memperoleh kekuatan hidup dengan merespon dakwah al Qur'an, Itulah sebabnya al Qur'an berada di jantung kehidupan umat muslim.

Seorang yang beragama Islam wajib kiranya untuk semua umat islam mempelajari al Qur'an. Bukan tanpa alasan mengapa semua umat islam diwajibkan untuk mempelajarinya. Al Qur'an itu sendiri terdapat berbagai kandungan ilmu yang sangat bermanfaat bagi kita semua, salah satunya dalam bidang ilmu pengetahuan alam yang mana dalam QS. Al alaq terdapat proses perkembangan manusia dari dalam kandungan, ada juga dalam al Qur'an mengharamkan manusia utuk memakan daging babi ternyata dalam daging babi terdapat cacing pita yang sangat berbahaya bagi kesehatan manusia. Selain itu, al Qur'an juga dijadikan pedoman hidup manusia dimuka bumi ini karena didalam al Qur'an juga terdapat kisah sejarah zaman dahulu yang dapat kita ambil hikmahnya untuk kehidupan sekarang ini. Oleh karena itu semua umat wajib mempelajari al Qur'an yag dimulai daari sejak usia dini.

Mempelajari al Qur'an tentunya bisa menggunakan suatu cara atau metode agar pembeajarani al Qur'an lebih menyenangkan. Zaman sekarang terdapat berbagai macam cara mempelajari al Qur'an. Salah satunya yang terdapat di lingkungan pendidikan, dalam Bidang pendidikan ada begitu banyak cara yang digunakan agar bisa dengan cepat membaca al Qur'an, Namun tidak semua metode pembelajaran al Qur'an yang di ajarkan memperhatikan tajwid atau aturan-aturan membaca al Qur'an. Banyak juga pembelajaran-pembelajaran sekarang ini hanya memfokuskan pada hal cepat agar seseorang bisa membaca al Qur'an, tetapi tidak memperhatikan ilmu tajwidnya. Hal yang perlu di garis bawahi sekarang ini adalah bukan hal mudah untuk seorang bisa terbiasa membaca al Qur'an dengan benar tanpa hambatan apapun. Pada era globalisasi saat ini seseorang akan cenderung menyukai hal-hal yang berkaitan dengan gadget atau perkembangan zaman daripada dengan al Qur'an. Terutama bagi seorang anak-anak.hal ini menjadikan seorang anak terbiasa bermain gadget daripada membaca al Qur'an.

Secara tidak langsung anak yang sering bermain dengan gadget, membaca al Qur'annya pun pasti tidak sefasih bacaan anak yang terbiasa membaca al Qur'an. Idealnya seorang anak membaca al Quran harus sesuai dengan hukum-hukum tajwid yang berlaku, Bukan asal bisa mengucapkan suatu bacaan tetapi juga harus memperhatikan makhorijul huruf, panjang pendeknya suatu lafal, dan juga hukum-hukum tajwid yang terkandung dalam bacaan al Qur'an tersebut. Dengan begitu, apabila seorang anak yang masih usia dini ini sudah memperhatikan aturan-aturan dalam membaca al Qur'an maka sampai dewasa anak tersebut akan mengingat cara membaca al Qur'an yang tepat.

Seperti dalam peribahasa yang mengatakan bahwa "belajar di masa kecil bagaikan mengukir diatas batu sedangkan belajar di masa tua bagaikan mengukir di atas air. Dalam hal ini dapat disimpulkan bahwa jika seorang anak yang terbiasa mematuhi aturanaturan membaca al Qur'an maka sampai dimasa depannya pula anak tersebut juga akan masih mengigat cara membaca al Qur'an yang benar itu seperti apa, Dalam hal ini pula 
tidak menutup kemungkinan bahwa seseorang anak yang terbiasa mematuhi aturan sejak kecil maka dia akan terbiasa pula mematuhi aturan jika dia dewasa kelak. Hal inilah yang menjadikan pentingnya pembiasaan membaca al Qur'an sejak dini.

Peneliti berpendapat bahwa apabila seseorang berkeinginan kuat untuk membaca al Qur'an dengan sebaik-baiknya, maka perlu penguasaan huruf, harakat, kalimat serta ayat-ayat. Maka dari itu belajar tajwid sangat perlu mendapatkan perhatian khusus, agar dalam membaca al Qur'an dapat terlaksana dengan baik dan benar perlu diberikan sejak usia kanak-kanak, sehingga pada saat dewasa penguasaan membaca al Qur'an sudah memenuhi kaidah-kaidah yang ditentukan, Untuk mendapatkan tingkat ketelitian tersebut perlu latihan-latihan secara berkesinambungan dan sungguh-sungguh, baik secara sendirian maupun kelompok. Di samping itu, diperlukan pula adanya kesopanan dan bimbingan dalam membaca al Qur'an.

Madrasah Ibtidaiyah Matholiul Falah Payaman Ngraho Bojonegoro salah satu lembaga pendidikan islam yang menerapkan pembiasaan membaca menulis al Quran dengan menggunakan metode yang berbeda dari sekolah atau lembaga pendidikan lainnya. Jika umumnya sekolah menggunakan metode Iqra' ataupun lainnya, maka di Madrasah Ibtidaiyah Matholiul Falah Payaman Bojonegoro ini menggunakan metode Jet tempur.

penggunaan metode ini mengutamakan kemampuan pribadi masing-masing siswa, sehingga hasil pembelajaran antar siswa satu dengan siswa yang lain bisa berbeda walaupun waktu yang disediakan sama. Biasanya seorang anak yang membaca al Qur'annya jarang ataupun bahkan tidak memperhatikan tajwidnya, semisal tidak memperhatikan panjang, pendek suatu bacaan, pengambilan nafas waktu di tengahtengah ayat, bahkan salah dalam pengucapan bacaan yang seharusnya di baca idzhar (jelas) di baca mendengung maka perlu dibimbing secara khusus dalam kelompok yang sesuai dengan kemampuan mereka.

Dari paparan diatas maka dapat difahami membaca dan menulis al Quran dengan benar adalah sangatlah penting. Berdasarkan pengamatan sementara tersebut mendorong penulis untuk meneliti kasus yang berjudul "BACA TULIS AL QUR'AN DENGAN METODE JET TEMPUR DI MADRASAH IBTIDAIYAH MATHOLIUL FALAH PAYAMAN NGRAHO BOJONEGORO". Alasan memilih MI Matholiul Falah Payaman Ngraho Bojonegoro karena di Madrasah Ibtidaiyah tersebut yang menerapkan Membaca dan Menulis Al-Quran secara rutin yang memudahkan penulis untuk memperoleh data dan meneliti penerapan membaca dan menulis al Quran dengan metode Jet Tempur MI Matholiul Falah Payaman Ngraho Bojonegoro.

\section{Pembelajaran al Qur'an}

Belajar adalah aktivitas yang menghasilkan perubahan pada diri indivisu yang belajar, baik aktual maupun potensial. Belajar al Quran adalah langkah - langkah yang tersusun secara terencana dan sistematis dengan menggunakan teknik dan metode tertentu dalam proses pembelajaran al Quran untuk mencapai tujuan yang diinginkan. Baca tulis al Qur'an merupakan salah satu program yang ada didalam lembaga pendidikan islam. Keberhasilan lembaga pendidikan islam dalam menyelenggarakan pendidikan sangat ditentukan oleh kemampuannya dalam dalam mengimplementasikan fungsi - fungsi menejemen secara profesional. fungsifungsi dalam manajemen lembaga pendidikan islam diawali dari perencanaan, pengorganisasian, pengarahan, dan pengawasan. Dalam proses pembelajaran bisa dilihat pengimplementasian Jurnal Riset Madrasah Ibtidaiyah (JURMIA). Vol. 1, No.1 
fungsi dari suatu lembaga pendidikan islam. Maju tidaknya suatu lembaga pendidikan dapat dilihat dari penerapan fungsi manajemen lembaga pendidikan islam itu sendiri.

Proses pembelajaran merupakan proses peningkatan kompetensi peserta didik yang direncanakan atau didesain, dilaksanakan, dan dievaluasi secara sistematis. Sebelum melakukan suatu proses pembelajaran sebuah lembaga pendidikan islam tentunya mempunyai perencanaan. Yang mana perencanaan itu sendiri merupakan proses kegiatan yang rasioanal dan sistemik dalam menetapkan keputusan, kegiataan atau langkah-langkah akan dilaksanakan kemudian hari dalam rangka usaha mencapai tujuan secara efektif dan efisien. Sedangkan perencanaan pendidikan adalah pemilihan fakta-fakta dan usaha menghubung-hubungkan antara fakta yang satu dengan fakta yang lain dalam aktivitas pendidikan, kemudian mempresiksi keadaan dan perumusan tindakan kependidikan untuk masa yang akan datang yang sekiranya diperlukan untuk mencapai hasil yang dikehendaki dalam pendidikan. Makna perencanaan diatas mengandung arti : 1. Manajer/pimpinan memikirkan dengan matan terlebih daahulu sasaran (tujuan) dan tindakan berdasarkan pada beberapa metode, rencana, atau logika dan bukan berdasarkan perasaan. 2. Rencana mengarahlan tujuan organisasi dan menetapkan prosedur terbaik untuk mencapainya. 3. Rencana merupakan pedoman untuk pedoman untuk organisasi dalam memperoleh dan menggunakan sumberdaya yang diperlukan untuk mencapai tujuan.

\section{Metode Jet Tempur}

Metode Jet Tempur merupakan sebuah metode yang di sandarkan pada buku Jet Tempur sebagai acuannya. Buku ini merupakan buku terbitan Madrasah Murottil Qur'anil Karim Pondok Pesantren Lirboyo Kediri. Ciri khas dari metode jet tempur ini terletak pada bentuk tulisan yang digunakan sama seperti tulisan al Qur'an Rosm Utsmani.

Metode jet tempur ini di lakukan secara bertahap di mulai dari yang paling dasar dahulu, bukan metode sulapan yang menggunakan sistem cepat kilat berapa jam bisa membaca al Qur'an. Memang banyak sekarang ini suatu pembelajaran menggunakan sistem cepat kilat membaca al Qur'an seperti sebuah sulapan yang langsung bisa pandai.

Namun terkadang beberapa metode cepat kilat membaca al Qur'an tidak memperhatikan aturan-aturan yang harus diikuti dalam membaca al Qur'an atau biasa disebut dengan tajwidnya. Sebenarnya Tujuan agama memerintahkan untuk mengaji al Qur'an adalah seseorang senantiasa berpedoman terus-menerus terhadap al Qur'an secara tidak langsung akan menjadikan orang islam yang mampu berjati diri. Dalam mempelajari metode jet tempur ini dimulai dari huruf hijaiyah yang harus sesuai dengantempat keluarnya huruf (makhorijul huruf)nya yang benar atau cara pengucapan masing-masing huruf dengan benar, lalu mempelajari tentang hukum- hukum Tajwidnya yang terdiri dari berbagai hukum mad, hukum bacaan nun sukun dan tanwin, dan lain sebagainya. Dengan mempelajari metode Jet Tempur ini seorang peserta didik akan mempelajari aturan-aturan membaca al Qur'an secara mendalam.

Metode jet Tempur dimulai dari pendalaman ilmu tajwid. Ilmu tajwid yang di pelajari antara lain :
a. Huruf hijaiyah
b. Memahami tajwid

Setelah mempelajari hal-hal yang berkaitan dengan tanjwid langkah selanjutnya yaitu mempelajari surat-surat pendek yang di mulai dari Q.S al Fatihah,Q.S an Nas, Q.S al Alaq, Q.S al Ikhlas, Q.S al Lahab, Q.S an Nashr, Q.S al Kafirun, Q.S al Kautsar, Q.S al Ma'un, Q.S al Quraisy, Q.S al Fiil, Q.S humazah, Q.S al Ashr, Q.S at Taktsur, Q.S al Qari'ah, Q.S al Adiyat, Q.S al Zalzalah, Q.S al Bayyinah, Q.S al Qadr, Q.S al Alaq, Q.S at Tin, Q.S ad Dhuha, Q.S al Lail, Q.S asy syamsi, Q.S al Balad, Q.S al Fajr, Q.S al Ghosiyah, Q.S al A'la. Setelah 
mempelajari surat-surat pendek selanjutnya akan mempelajari tentang dua surat pilihan yaitu Q.S al Waqiah dan Q.S Yasin.

\section{METODE PENELITIAN}

\section{Pendekatan Penelitian}

Penelitian yang digunakan ini adalah penelitian kualitatif. Penelitian kualitatif adalah penelitian yang berlandaskan pada filsafat postpositivisme, digunakan untuk meneliti pada objek yang alamiyah, (sebagai lawannya adalah eksperimen) data dilakukan secara trianggulasi (gabungan), analisis data bersifat induktif/kualitatif, dan hasil penelitian lebih menekankan maknadari generalisasi. Alasan menggunakan jenis penelitian ini karena jenis penelitian ini sangat sesuai dengan penelitian yang saat ini dilakukan yang haislnya berupa penjelasan atau jabaran suatu penelitian.

Maleong mengatakan bahwa "penelitian kualitatif berakar pada akar alamiah sebagai keutuhan, mengandalkan manusia sebagai alat penelitian, memanfaatkan metode kualitatif, mengadakan analisis dan secara induktifmengarahkan sasaran peelitiannya pada usaha menemukan teori dari dasar, bersifat deskriptif lebih mementingkan proses daripada hasil, membatasi studi dengan fokus, memiliki seperangkat kriteria untuk memeriksa keabsahan data, rancangan penelitiaannya bersifat sementara dan hasil penelitiannya di sepakati oleh kesua belah pihak, yakni peneliti dan subyek peneliti". Berdasarkan pendapat tersebut, maka penelitian ini diarahkan pada proses pembelajaran baca tulis al Qur'an dengan menggunakan metode Jet Tempur di MI Matholiul Falah Payaman Ngraho Bojonegoro.

2. Jenis Penelitian

Penelitian ini menggunakan pendekatan deskriptif kualitatif. Pendekatan ini merupakan proses pengumpulan data dengan cara mendeskripsikan atau menggambarkan data yang berupa kata-kata tertulis atau lisan dari orang-orang dan perilaku yang diamati. Alasan penggunaann Pendekatan ini karena penelitian ini berupa narasi deskriptif.

3. Lokasi Penelitian

Lokasi penelitian terletak di MI Matholiul Falah Payaman Kecamatan Ngraho Kabupaten Bojonegoro. Peneliti memilih Madrasah ini karena di sinilah menggunakan metode pembelajaran baca tulis yang berbeda dengan madrasah yang lain yaitu dengan menggunakan metode jet tempur.

4. Data dan Sumber

Adapun data yang diambil oleh peneliti adalah sumber data yang berupa katakata dan tindakan serta sumber data tambahan yang berupa dokumen-dokumen. Sumber data yang digunakan dalam penelitian ini adalah sebagai berikut :

a. sumber data utama (primer) Data Primer adalah data yang diambil peneliti melalui observasi dan wawancara. Sumber data meliputi : 1. Kepala Madrasah MI Matholiul Falah Payaman Ngraho Bojonegoro tentang metode jet tempur. 2. Para Ustadzah (Guru) MI Matholiul Falah Payaman Ngraho Bojonegoro tentang metode jet tempur.Siswa MI Matholiul Falah Payaman Ngraho Bojonegoro tentang metode jet tempur. d. Kegiatan proses pembelajaran baca tulis al Qur'an MI Matholiul Falah Payaman Ngraho Bojonegoro.

b. Sumber data tambahan (sekunder) 
Sumber data tambahan yang digunakan penulis dalam penelitian ini adalah terdiri atas dokumen-dokumen sebagai berikut : a. letak geografis MI Matholiul Falah Payaman Ngraho Bojonegoro. b. Data guru, pegawai dan siswa MI Matholiul Falah Payaman Ngraho Bojonegoro. c. Sarana dan prasaranaMI Matholiul Falah Payaman Ngraho Bojonegoro.

5. Teknik Pengumpulan

Data Teknik pengumpulan data adalah ketetapan cara-cara yang digunakan oleh peneliti untuk mengumpulkan data. Pengumpulan data dapat dilakukan dalam berbagai sumber dan berbagai cara. Secara umum teknik pengumpulan data adalah alat bantu yang digunakan peneliti untuk mengumpulkan data penelitian. Dalam penelitian kualitatif, pengumpulan data dilakukan natural setting, sumber data primer dan teknik pengumpulan data lebih banyak pada observasi, berperan dalam wawancara, dan dokumentasi.

6. Teknik analisis data

Teknik analisis data yang digunakan dalam penelitian ini adalah menggunakan langkah - langkah berikut :

a. Reduksi Data ( Data Reduction) Data yang diperoleh dari lapangan jumlahnya cukup banyak, untuk itu maka perlu dicatat secara teliti dan rinci. Seperti telah dikemukakan, semakin lama peneliti ke lapangan, maka jumlah data akan semakin banyak, komplek, dan rumit. Untuk itu perlu segera dilakukan analisis data melalui reduksi data. Mereduksi data berarti merangkum, memilih hal-hal yang pokok, memfikuskan hal-hal yang penting, dicari tema dan polanya. Dengan demikian data yang telah direduksi akan memberikan gambaran yang lebih jelas, dan mempermudah peneliti untuk melakukan pengumpulan data selanjutnya, dan mencarinya bila diperlukan. Jadi, dapat disimpulkan bahwa reduksi data merupakan memilih hal yang penting, membuat kategori, dan membuang hal-hal yang tidak penting.

b. Display Data

Setelah data direduksi, maka selanjutnya adalah mendisplaykan data. Dalam penelitian kualitatif, penyajian data bisa dilakukan dalam bentuk uraian singkat, bagan hubungan antar kategori, flowchart,dan sejenisnya. Dalam penelitian ini peneliti menyajikan data dengan teks yang bersifat naratif.

c. Verifikasi dan Penarikan Kesimpulan (concluction Drawing and Verification) Langkah ketiga dalam analisis kualitatif adalah penarikan kesimpulan dan verifikasi. Kesimpulan awal yang dikemukakan masih bersifat sementara, dan akan berubah bila tidak ditemukan bukti-bukti yang kuat yang mendukung pada tahap pengumpulan data selanjutnya. Tetapi apabila kesimpulan yang dikemukakan pada tahap awal, didukung oleh buktibukti yang valid dan konsisten saat peneliti kembali ke lapangan mengumpulkan data, maka kesimpulan yang dikemukakan merupakan kesimpulan yang kredibel.

\section{HASIL DAN PEMBAHASAN}

1. Pembelajaran al Qur'an MI Matholiul Falah Payaman Ngraho Bojonegoro. 
Suatu lembaga Pendidikan pasti terjadi yang namanya kegiatan belajar mengajar atau yang lebih sering dinamakan dengan kegiatan pembelajaran. Kegiatan pembelajaran terjadi apabila terjadi interaksi antara guru dengan siswanya. Baik interaksi yang berpusat pada guru ( teacher center) maupun yang berpusat pada siswa (student center). Adapun pembelajaran yang menggunakan teacher center semisal saat guru mengajar menggunakan model pembelajaran langsung dengan metode ceramah. Sedangkan pembelajaran yang berpusat pada siswa semisal saat pembelajaran bermain peran dimana siswa lebih aktif dari pada gururnya. Keberhasilan MI Matholiul Falah Payaman Ngraho Bojonegoro dalam menyelenggarakan pendidikan sangat ditentukan oleh kemampuannya dalam dalam mengimplementasikan fungsi - fungsi managemen secara profesional. Fungsi-fungsi dalam manajemen Keberhasilan MI Matholiul Falah Payaman Ngraho Bojonegoro diawali dari perencanaan, pengorganisasian, pengarahan, dan pengawasan profesional.

Sebagai contoh dalam melakukan suatu pembelajaran guru menyiapkan materi pembelajaran yang akan disampaikan kepada siswa. Langkah selanjutnya yaitu pengorganisaian yang mana dalam pengimplementasiannya pendidik melakanakan pembelajaran yang telah direncanakan sebelumnya. Pengarahan disini dilihat dari selama pembelajaran peserta didik yang merasa dirinya kurang memahami materi akan dibimbing. pendidik sampai peserta didik mencapai standar kompetensi yang telah ditentukan. Langkah terakhir yaitu pengawasan yang mana pendidik mengevaluasi setiap pembelajaran dan menindaklanjuti kekurangan dalam penyampaian materi pembelajaran. Pembelajaran di MI Matholiul Falah Payaman Ngraho Bojonegoro bukan hanya terfokus pada pembelajaran mata pelajaran umum saja, namun juga terfokus pada mata pelajaran agama.

Madrasah Ibtidaiyah Matholiul Falah Payaman Ngraho Bojonegoro menekankan pada Pembelajaran agamanya. Mata pelajaran agama yang paling menonjol adalah pembelajaran tentang al Qur'an. Alasannya karena al Qur'an dijadikan bekal bagi peserta didik untuk kehidupan masa yang akan datang. Dengan dari kecil seorang anak di ajari tentang al Qur'an di harapkan sampai usia dewasa anak tidak akan jauh dari perihal keagamaan. Dalam mempelajari al Qur'an seorang pendidik tidak boleh mengajarkan al Qur'an dengan salah tanpa memperhatikan kaidah dalam penlafalan al Qur'an sebab apabila seorang pendidik salah dalam melafalkan al Qur'an, maka peserta didikpun akan salah dalam melafalkannya. Dalam mempelajari al Qur'an tentunya 58 seorang pendidik harus menguasai ilmu tajwid. Ilmu tajwid adalah ilmu yang mempelajari bagaimana cara membunyikan atau mengucapkan huruf-huruf yang terdapat yang terdapat dalam kitab suci al Qur'an ataupun buka. Adapun masalah - masalah yang di kemukakan dalam ilmu tajwid antara lain makhorjul huruf (tempat keluar-masuknya huruf) dan hukum bacaan suatu lafadz seperti bacaan mad thobi'i, lein,qolqolah, hamzah wahol dan hamzah Qotho', ghunnah, bacaan lam jalalah, tanda-tanda waqaf, bacaan nun mati dan tanwin, hukum bacaan mim sukun, bacaan ro' sukun, mad wajib muttasil, mad jaiz munfasil, mad lazim, dan bacaan ghorib. MI Matholiul Falah Payaman Ngraho Bojonegoro kegiatan pembelajaran al Qur'an dilakukan di pagi hari yang dilaksanakan Hari selasa, kamis, dan ahad pukul 06:45 - 07 :30.

Adapun Proses pembelajaran dalam pembelajaran al Qur'an antara lain :

1. Membaca doa pendek Harian.

2. Membaca surat alfatihah dan surat-surat pendek sesuai dengan tingkatannya.

3. Membaca materi yang ada di jet tempur sesuai tingkatannya.

4. Menulis materi yang ada di jet tempur sesuai tingkatannya.

5. Di private sesuai dengan ngajinya masing- masing. 

6. Penilaian .
7. Berdoa Penutup

\section{Pembelajaran Baca Tulis Al Qur'an Dengan Metode Jet Tempur}

Metode jet tempur adalah sebuah metode baca tulis al Qur'an yang di terbitkan oleh KH. Maftuh Bastul Birri Pengasuh PP. Lirboyo Kediri. 48 Metode ini diciptakan sehubungan dengan pembelajaran al Qur'an yang menggunakan Rosm Usmani. Jadi, metode ini sangat berbeda dengan metode yang lain karena metode ini di tekankan pada : 1. Rosm ( tulisan al Qur'an ) 2. Membaca dan menghafal Alasan madrasah ini menggunakan metode jet tempur pada pembelajaran baca tulis al Qur'an adalah metode ini yang paling cocok dan relevan dengan al Qur'an yang original yaitu al Qur'an Rosm Utsmani.

1. Tujuan pembelajaran

Segala aktifitas mempunyai tujuan yang ingin dicapainya, begitu pula dengan pembelajaran baca tulis al Qur'an ini. Setelah berdialog dengan ustadz bisri selaku pendidik baca tulis al Qur'an di MI Matholiul Falah Payaman Ngraho Bojonegoro bahwa tujuan yang ingin di capai dalam proses pembelajaran baca tulis al Qur'an adalah melahirkan generasi yang Qur'ani yang artinya generasi yang mencinta al Qur'an.

2. Target yang di harapkan

Target yang di harapkan dari pembelajaran baca tulis al Qur'an dengan metode jet tempur ini adalah peserta didik lebih menguasai al Qur'an baik dalam segi bacaan maupun tulisanya. Alasannya karena apabila peserta didik membaca al Qur'an namun tidak sesuai kaidah yang berlaku maka akan mengubah makna dari lafadz al Qur'an tersebut.

3. Waktu kegiatan

Pelaksanaan kegiatan belajar mengajar baca tulis al Qur'an dengan metode jet tempur di MI Matholiul Falah yaitu : Hari selasa, kamis, dan ahad pukul 06:45 - 07 :30. Alasan di jadwalkan pada waktu pagi adalah membiasakan peserta didik mengaji al Qur'an sebelum melakukan aktifitas dan pada waktu pagi hari otak anak masih freh.

4. Proses Pembelajaran

Untuk mengetahui lebih detail tentang proses pembelajaran baca tulis al Qur'an menggunakan metode jet tempur, peneliti melakukan wawancara dengan ustadz ustadzah dan melakukan observasi saat pembelajaran langsung. Baca tulis al Qur'an di MI Matholiul falah Payaman di bagi menjadi 3 tingkatan yaitu tingkatan pemula, lanjutan, dan tahfidz. Di bagi menjadi 3 tingkatan alasannya adalah mempermudah penyampaian mater sesuai dengan kemampuan peserta didik. Adapun klasifikasi kelas pembelajran dengan metode jet temput adalah sebgai mana berikut;

a. Tingkat pemula

Tingkatan pemula adalah tingkatan yang paling dasar. Peserta didik yang termasuk tingkatan pemula ini adalah peserta didik baru yang masuk di MI Matholiul Falah Payaman Ngraho Bojonegoro baik masuk kelas 1 ataupun yang pindahan, dan peserta didik yang kemampuan membacanya belum bisa membedakan bacaan mad ( panjang pendeknya bacaan) dalam satu kata. Pada tingkatan ini terdiri dari 6 kelompok, hal ini dilakukan agar pada saat pembelajaran lebih efisien dan tidak memakan waktu yang lama.

b. Tingkat lanjutan

Tingkatan lanjutan merupakan tahap lanjutan dari pemula. Pada tingkatan ini terdiri dari 3 kelompok. Dijadikan 3 kelompok agar pada saat pembelajaran bisa lebih efisien dan tidak memakan waktu yang lama. Pada tingkatan ini di tekankan pada membaca dan potongan ayat-ayat al Qur'an Pembelajaran tajwid yang di pelajarari mulai seperti bacaan mad thobi'i, lein,qolqolah, hamzah wahol dan hamzah Qotho', 
ghunnah, bacaan lam jalalah, tanda-tanda waqaf, bacaan nun mati dan tanwin, hukum bacaan mim sukun, bacaan ro' sukun, mad wajib muttasil, mad jaiz munfasil, mad lazim, dan bacaan ghorib. Ujian naik tingkatan dengan membaca surat- surat pendek.

c. Tingkat tahfidz

Tahapan tahfidz adalah tapan selanjutnya dari lanjutan. Pada tingkatan ini peserta didik ditekankan pada pematangan pembelajaran tajwidnya yang meliputi hukum bacaan mad thobi'i, lein,qolqolah, hamzah wahol dan hamzah Qotho', ghunnah, bacaan lam jalalah, tanda-tanda waqaf, bacaan nun mati dan tanwin, hukum bacaan mim sukun, bacaan ro' sukun, mad wajib muttasil, mad jaiz munfasil, mad lazim, bacaan ghorib secara langsung dalam praktiknya dan fokus pada hafalan surat juz 30 dan surat - surat pilihan seperti QS. Yasin dan QS. al - Waqiah. Batasan penghafalan surat ataupun ayat tergantung pada kemampuan siswa masing-masing. Semakin banyak dia menghafal al Qur'an maka semakin cepat pula menyelesaikannya. Pada tingkatan ini terdiri dari 3 kelompok. Hal ini dilakukan agar pada saat pembelajaran lebih efisien dan tidak memakan waktu yang lama.Evaluasi tingkatan tahfidz di uji dalam bentuk hafalan juz 30 dan Q.S yasin dan Q.S al Waqiah.

\section{FAktor Penghambat Dan Pendukung Pembelajaran Al Qur`An Dengan Metode Jet Tempur}

a. Faktor Pendukung

Faktor pendukungnya antara lain: 1) Kemampuan pendidik dalam menguasai materi. Madrasah Ibtidaiyah Matholiul Falah Payaman Ngraho Bojonegoro mempunyai kegiatan baca tulis al Qur'an dengan menggunakan metode jet tempur. Dimana dengan metode ini setiap pendidik di haruskan untuk menguasai metode penyampaian dan penguasaan materi yang akan di sampaikan ke peserta didik. Kemampuan pendidik dalam melaksanakan pembelajaran sangatlah penting. Hal ini bisa dilihat apabila seorang pendidik menguasai materi pembelajaran, maka semakin mudah pula pendidik dalam menyampaikan materi ke peserta didik. Sebaliknya apabila seorang pendidik tidak menguasai materi yang akan di sampaikan maka semakin sulit pula peserta didik menyerap materi yang disampaikan. Menurut peneiti seharusnya sebelum melaksanakan kegiatan baca tulis al Qur'an setiap pendidik melakukan briefing baca tulis al Qur'an antar pendidik agar mencapai target yang diharapkan. 2) Keaktifan peserta didik dalam pembelajaran. Setiap madrasah memiliki aneka ragam sifat dari peserta didik. Adaa yang aktif, malas - malasan, suka bercerita dengan temannya, dan lain- lain. Hal ini juga mempengaruhi pembelajaran. Dalam pembelajaran baca tulis al Qur'an di MI Matholil Falah Payaman Ngraho Bojonegoro partisipasi keaktifan peserta didik menjadi tolok ukur yang sangat. Hal ini peneliti perhatikan pada saat pembelajaran baca tulis al Qur'an. Peserta didik yang aktif dalam mengikuti intruksi dan mempraktekkan setiap arahan dari pendidik akan semakin cepat dalam menyerap materi yang disampaikan. 3) Menejemen kelas. Menejemen pengelolaan kelas yang telah di atur seorang pendidik menjadi faktor pendukung selanjutnya. Hal ini dilihat dari menejemen pengelolaan kelas yang ada di pembelajaran baca tulis al Qur'an di MI Matholiul Falah Payaman Ngraho Bojonegoro yang mana setiap pendidik hanya memegang 10-15 peserta didik dalam setiap kelompokang menjadikan keaktifan peserta didik dalam mengikuti pembelajaran sebagi faktor pendukung.

b. Faktor Penghambat

Adapun faktor penghambat baca tulis al Qur'an antara lain : 1) Kurangnya media pembelajaran. Dalam penyampaian materi pembelajaran baca tulis al Quran dengan metode jet tempur di MI Matholul falah Payaman Ngraho Bojonegoro pada prakteknya 
terdapat kendala pada waktu pembelajaran salah satunya adalah kurangnya media pembelajaran. Hal ini peneliti perhatikan saat Pendidik melaksanakan pembelajaran tetapi tidak menggunakan media pembelajaran maka pembelajaran terasa kurang menarik dan membosankan. 2) Monotonnya pendidik dalam menyampaikan materi. Penyampaian materi pembelajaran dalam baca tulis al Qur'an terasa monoton karena pada waktu penyampaian materi baca tulis al Qur'an pendidik selalu menggunakan metode ceramah, yang mana pada hal ini seorang peserta didik hanya mendengarkan penjelasan dari pendidik. Menurut peneliti seorang pendidik seharusnya menggunakan inovasi terbaru untuk penyampaian materi baca tulis al Qur'an agar lebih menyenangkan. 3) Kedisiplinan siswa. Salah satu yang menjadi faktor penghambat baca tulis al Qur'an yang ada di MI Matholiul Falah Payaman Ngraho Bojonegoro adalah faktor kedisplinan peserta didik. Waktu pelakasanaan baca tulis al Qur'an dilaksanakan pada waktu pagi hari sehingga ada banyak peserta didik yang datang terlambat dengan berbagai macam alasan yang di kemukakan. Menurut peneliti keterlambatan siswa yang datang ini menjadikan penyampaian materi baca tulis al Qur'an menjadi terganggu.

\section{KESIMPULAN DAN SARAN}

Proses pembelajaran al qur`an metode jet tempur di MI Matholiul Falah Payaman Ngraho Bojonegoro proses pembelajarannya adalah membaca doa, membaca surat alfatihah dan suratsurat pendek sesuai dengan tingkatannya. Membaca materi yang ada di jet tempur sesuai tingkatannya, menulis materi yang ada di jet tempur sesuai tingkatannya, di private sesuai dengan ngajinya masingmasing, penilaian, berdoa.

Faktor pendukung faktor pendukung baca tulis al qur'an degan metode jet tempur adalah kemampuan pendidik dalam menguasai materi, keaktifan peserta didik dalam mengikuti pembelajaran dan manajemen kelas.

Faktor penghambat faktor penghambat baca tulis al qur'an dengan metode jet tempur sekaligus menjadika saran adalah kurangnya media pembelajaran, monotonnya pendidik dalam menyampaikan materi dan kedisplinan peserta didik. Pendidik harus sangat memperhatikan faaktor ini agar metode yang dipakai dapat maksimal.

\section{DAFTAR PUSTAKA}

Al-Jurri. (2018). Akhlak Orang Berilmu dan Ahli Qur'an,Banten :Pustaka Alvabet.

Al- Gharani, Ibnu Marzuki. (2018). Buku Pintar Khutbah Jumat Tematik.Yogyakarta : Laksana.

Al Hakim, Zidna Kamila Interview. (2020). Proses Pembelajaran Baca tulis al Quran: Bojonegoro.

Anggraini, Desi Interview. (2020). Proses Pembelajaran baca Tulis al Qur'an Metode Jet Tempur. Bojonegoro.

Anonim. (2011). Sertifikasi Guru Mengajar Metode Ummi, Surabaya: Ummi Fondation.

Arikunto. (2016). Prosedur penelitian suatu pendekatan praktek. jakarta: PT. Rienika Cipta.

Arwani, M Ulil Albab dkk. (2018). Thariqoh Baca al Qur'an . Surabaya : Laksana. 
Bisri Interview. (2020). Baca Tulis al Qur'an dengan Metode Jet Tempur. Bojonegoro.

Departemen Agama RI. (2014). Al-Qur'an dan terjemahannya,(Bandung:Diponegoro)

Elfira Interview. (2020). Proses Pembelajaran Baca Tulis al Qur'an metode Jet Tempur. Bojonegoro.

Evendi, Moh. (2018). Penggunaan Metode Iqra' dalam meningkatkan kemampuan baca Al Qur'an anak di Taman Pendidikan Quran Nurul Islam Bayemgede Kepohbaru Bojonegoro, Skripsi tidak diterbitkan. Bojonegoro : Program Sarjana S1 IAI Sunan Giri Bojonegoro.

Gunawan \& Darmani. (2016). Model dan Strategi Pembelajaran Aktif dan Menyenangkan, Sidoarjo:Nizamia Learning center.

Hamid, Abdul. (2016). Pengantar Studi al Qur'an, Jakarta : Kencana.

Lexy, Moeloeng. (2010). Metodelogi Penelitian Kualitatif, Bandung: Remaja Grafindo Persada.

Maujud, Fathul. (2018). Implementasi Fungsi-Fungsi Manajemen dalam lembaga Pendidikan Islam . Jurnal Penelitian Keislaman. Vol.14, no.1.

Maula Ibnu Rusyid, Raisya. (2019). Panduan Praktis \& Lengkap Tahsin, Tajwid, Tahfidz untuk Pemula, Yogyakarta:Laksana.

Majid Khon, Abdul. (2015). Hadis Tarbawi :Hadis - Hadis Pendidikan,Jakarta : Prenada Media.

Mulyani, Ulum. (2020). Proses Pembelajaran Baca Tulis al Qur'an metode Jet Tempur . Bojonegoro.

Mustofiyah, Durriyah. (2018). Studi Komparasi antara kemampuan baca tulis al Qur'an dengan menggunakan metode yanbua di MI NU Raudlatut ThalibinKudus dan Metode Iqra di MI Muhammadiyah Kudus., Skripsi tidak di terbitkan. Kudus: Program Sarjana UIN Walisongo Semarang.

Rohmah, Siti Ainur Interview. (2020). Proses Pembelajaran Baca Tulis al Qur'an metode Jet Tempur. Bojonegoro.

Rosadi,Imron. (2013). Siapa takut menulis. Yogyakarta: Kanisius.

Sirojuddin dan Maftuh Batsul Birri. (2016). Pengantar Mengaji al Qur'an dengan turutan A Ba Ta Jet Tempur. Kediri : Madrasah Murattilil Qur'anil karim.

Sugiono. (2016). Metode Penelitian Kuantitatif, Kualitatif, dan R\&D. Bandung:Alfabeta. 